\title{
The effects of different variables on the direct screw withdrawal strength in plywood
}

\author{
Huseyin YORUR ${ }^{1 *}$, Onder $\mathrm{TOR}^{2}$, Muhammed Nuri GUNAY ${ }^{1}$, Emre BIRINCI $^{3}$
}

\author{
${ }^{1}$ Karabuk University, Faculty of Forestry, Forest Engineering Department, Karabuk, Turkey \\ ${ }^{2}$ Kastamonu University, Faculty of Forestry, Forest Engineering Department, Kastamonu, Turkey \\ ${ }^{3}$ Kastamonu University, Arac R.V. Vocational School and Higher Education, Kastamonu, Turkey \\ *Corresponding author: huseyinyorur@karabuk.edu.tr
}

Received Date: 10.08.2017

Accepted Date: 21.08 .2017

\section{Abstract}

Aim of study: The purpose of this study was to investigate the effect of the pilot-hole, screw type, screwing direction, water soak and adhesive on the screw withdrawal strength in plywood.

Material and Methods: Testing blocks were cut from 18-mm-thick beech plywood and were sized to 50 $\mathrm{mm}$ x $50 \mathrm{~mm}$ according to TS EN 13446 standards. Polyvinyl acetate (PVAc) and polyurethane (PU) as adhesives were injected into predrilled holes ( $80 \%$ of the screw major diameter). Two types of screws (3.5 $\mathrm{mm}$ and $4 \mathrm{~mm}$ in diameter) were inserted in perpendicular (face) and parallel (edge) to the surface of blocks. Half of the blocks were immersed in water for 2 hours before the screw withdrawal test. The results were analyzed and interpreted by statistical analysis.

Main results: The results indicated that the screw withdrawal strength perpendicular to the surface is higher than that the one parallel to the surface. The testing blocks with PU specimens in pilot-hole showed higher screw withdrawal strength than the blocks with PVAc. The screw withdrawal strength was lower when blocks were immersed in water. It was also found that the screw withdrawal strength increases, as the screw major diameter increases.

Research highlights: It was concluded that applying PU in pilot-holes before driving screw into plywood significantly affected screw withdrawal performance.

Keywords: Screw withdrawal, Plywood, Pilot-hole, Polyvinyl acetate, Polyurethane

\section{Kontrplakta farklı değişkenlerin vida çekme direnci üzerindeki etkisi}

Özet

Çalışmanın amacı: Kontrplağın vida çekme direnci üzerine kılavuz deliğinin, vida tipinin, vidalama yönünün, suda bekletmenin ve yapıştırıcının etkisini araştırmaktır.

Materyal ve Yöntem: Çalışmada çapları sırasıyla $3.5 \mathrm{~mm}$ ve $4 \mathrm{~mm}$ olmak üzere 2 tip vida kullanılmıştır. Temin edilen $18 \mathrm{~mm}$ kalınlığındaki kontrplak TS EN 13446 standardına göre $50 \mathrm{~mm}$ x $50 \mathrm{~mm}$ boyutlarında ebatlandırılmıştır. Kılavuz deliğinin çapı, testlerde kullanılan vida çapının \%80’i olacak şekilde delme işlemi yapıldı. Polivinil asetat (PVAc) ve Poliüretan (PÜ) tutkalları kılavuz deliklerine enjekte edildikten sonra örnek yüzeyine ve kenarına vidalama işlemi gerçekleştirildi. Örneklerin yarısı 2 saat süre ile suda bekletildikten sonra vida çekme testleri yapıldı. Testlerin sonuçları istatistik analiz ile yorumlandı.

Sonuçlar: Sonuçlar incelendiğinde kılavuz deliği açılmayan örnekler daha yüksek vida çekme direnci göstermiştir. Ayrıca yüzeyden uygulanan vida çekme direncinin kenardan uygulanana göre daha yüksek olduğu tespit edilmiştir. Tutkal uygulanan kılavuz delikli örnekler incelendiğinde Poliüretan (PÜ) uygulananların vida çekme mukavemeti Polivinil asetat (PVAc) uygulananlara göre daha yüksek olduğu belirlenmiştir. Suda bekletilmiş örnekler incelendiğinde daha düşük vida çekme mukavemeti göstermiştir. Ayrıca vida çapı arttıkça vida çekme mukavemetinin arttığı tespit edilmiştir.

Araştırma vurgularl: Kontrplakta vidalama öncesinde kılavuz deliklerine PÜ uygulanması vida tutma performasını önemli ölçüde etkilemektedir.

Anahtar Kelimeler: Vida çekme, Kontrplak, Kılavuz deliği, Polivinil asetat, Poliüretan 


\section{Introduction}

Wood and wood-based materials are the most common construction materials in terms of residential and commercial purposes (Yorur, 2016). One of the widely used woodbased material is plywood where it is suitable for floors, roofs, wall paneling, furniture, cabinets, counters. Since plywood can be used for a wide variety of interior and exterior applications, it is importantly necessary to protect this material due not to come into contact with especially water or moisture over time.

In order to connect wood and wood based composites to any wooden material or any other materials such as metal or plastics fasteners such as nails, bolts, dowels, screws and nail plates are used (Tor et al., 2016). The durability and rigidity of furniture construction depend largely on the screw performance such as screw driving torque and screw-holding ability in which some factors such as screw type, embedded screw orientation, pilot-hole diameter and penetration depth (Ors et al., 1998; Tor et al 2015; Tor et al., 2016; Eckelman \& Rajak, 1993; Eckelman, 1988; Eckelman, 1973; Eckelman, 1975; Eckelman, 1990).

Rajak and Eckelman (1993) reported that the pilot holes increased the screw holding strength in the face and edge surfaces of medium density fiberboard and particleboard. And so, the pilot holes should be equal to about $80-85 \%$ of the major diameter of the screw. However, in another study, it was reported that pilot-hole diameters did not affect the direct screw withdrawal when pilotholes were drilled between $50 \%$ and $90 \%$ of screw major diameter in particleboard and $40 \%$ and $70 \%$ in Douglas fir plywood (Carroll, 1970). Some other factors such as moisture content (MC), specific gravity and surface smoothness affected the screw withdrawal strength (SWS) (Rammer, 1999; Akyildiz \& Malkocoglu, 2001). The withdrawal strength of screw in a wood section with 30\% MC was lower than the one with 12\% MC (Akyildiz \& Malkocoglu, 2001).

A linear trend was found between withdrawal strength and screw major diameter in various investigations. However, there was no relationship between screw length and withdrawal strength (Eckelman, 1978; Ors et al., 1998). In a similar study about SWS, driving torque and withdrawal strength were increased by increasing the length of the screw (Fujimoto \& Mori, 1983).

Erdil Y. et all, (2002) worked on the holding strength of screws in different plywoods including SPLY-1 (5-ply southern pine with the density of $575 \mathrm{~kg} / \mathrm{m} 3)$, SPLY-2 (6-ply southern pine with the density of 581 $\mathrm{kg} / \mathrm{m} 3$ ), SPLY-3 (5-ply southern pine with the density of $589 \mathrm{~kg} / \mathrm{m} 3$ ) and their thicknesses were $18 \mathrm{~mm}$. Another type of plywood coded HPLY (6-ply with the density of $581 \mathrm{~kg} / \mathrm{m} 3$ ) with thickness of $19 \mathrm{~mm}$ was studied in this study. The results of this study indicated that the screw gage, pilot-hole diameter and board thickness can affect the perpendicular and direct screw withdrawal load in plywood and OSB. In the case of screw embedded orientation, screw holding strength in the edge of wood-based materials was lowest because the fasteners were inserted in the middle layer of panels (Eckelman \& Rajak, 1993).

In the case of using adhesive in pilot-holes before screwing affected the screw holding performance. A study on this subject indicated that, adding glue (PVA) in the pilot holes increased the screw holding strength by 9 $45 \%$ in parallel to the surface and $7-39 \%$ perpendicular to the surface (Senay, 1996). In a study, for laminated specimens that were prepared with beech layers of 2 and $4 \mathrm{~mm}$ thickness by the use of Polyurethane (PU) and Polyvinyl acetate (PVAc) glues. The withdrawal strengths of nail for the testing blocks prepared with PU glue was higher than those prepared with PVAc glue. The results on radial sections showed that the layer thickness did not affect the withdrawal strength of nail, whereas the type of glue used was effective (Senay, 1996).

The primary objective of this study was to obtain information about the characteristics of SWS into plywood. The specific objectives were 1) to obtain typical load-time graphs showing maximum screw withdrawal load during the course of screw withdrawal from plywood; 2) investigate the effects of type of pilot-hole, embedded screw orientation, major diameter of screw and water soak. With this study, plywood and furniture manufacturers 
can understand screw withdrawal performances of their products.

\section{Material and Method}

Experimental design

A complete three-factor factorial experiment with 7 replications per combination was conducted to evaluate factors on direct withdrawal of screws in plywood. The three factors were type of pilot-holes (no pilot-hole, pilot-holes at $80 \%$ of the major diameter of screw, pilot holes with PVAc and PU), embedded screw orientation (edge and face), major diameter of screw (3.5 and $4.0 \mathrm{~mm}$ ), and water soak (non-treated and water-

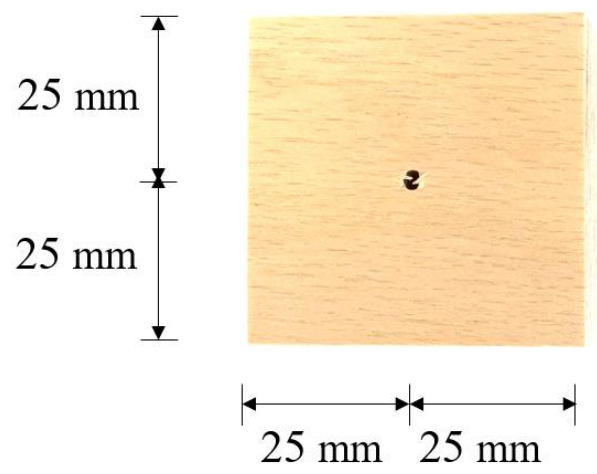

a) Face treated). Therefore, a total of 224 SWS tests were performed on 112 testing blocks. The nominal dimension of each testing block was $50 \mathrm{~mm}$ in length, $50 \mathrm{~mm}$ in width and $18 \mathrm{~mm}$ in thickness (TS EN 13446). The dimensions and orientations of a single block are shown in Figure 1. Plywood was beech plywood consisted of 11 veneer laid crossways to each other and bonded together with an adhesive. The screws were Philips flathead sheet metal screws made from zinc plated steel. The dimensions of two screw sizes used in this study were 3.5 in diameter $\times 45 \mathrm{~mm}$ in length and 4 in diameter $\times 45 \mathrm{~mm}$ in length.

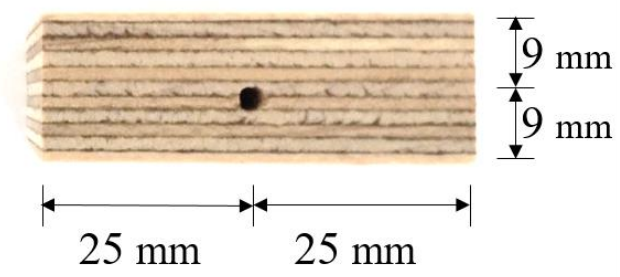

b) Edge

Figure 1. The dimensions and orientations of a single block

\section{Specimen Preparation and SWS Measurement}

The testing blocks were cut from full size of beech plywood panels $(2.5 \mathrm{~m} \times 1.25 \mathrm{~m})$ and were acclimatized at $(20 \pm 2){ }^{\circ} \mathrm{C}$ and $(65 \pm 5)$ $\%$ relative humidity for two weeks according to EN 320. The density of plywood was 700 $\mathrm{kg} / \mathrm{m}^{3}$. The testing blocks were separated into two groups. In the first group, the testing blocks were not immerse in water whereas the ones in the second group were immerse in water to determine the effect of water and type of adhesive on SWS into plywood. Type of pilot holes were selected as no pilot-hole (type I), only pilot- hole (type II) and pilot hole with PVAc (type III) and PU (type IV) and to perform the tests. PU and PVAc were used as mounting adhesive into the pilot-holes. The pilot-holes were drilled in the $(80 \%$ of screw major diameter) at the center of each embedded screw orientation for the type pilot hole of II, III, and IV. After the pilot-holes were drilled for type III and IV, the adhesives were poured into the pilot-holes (TS EN 13446) before driving the screws in the testing blocks. All testing blocks were prepared as specified above for both groups until this point. For the second group, half of the testing blocks were immersed in water two hours to fully prepared for the SWS test.

Screw withdrawal tests were carried out on a Zwick Rowell Testing Machine in accordance with EN 320 and TS EN 13446. As shown in Figure 2, one SWS test was performed into edge and face of the same block, separately.

\section{Results and Discussion}

Table 1 summarizes mean values of screw withdrawal load in plywood ranged from 713 to $3643 \mathrm{~N}$. In general, mean SWS values in the face of a specimen were significantly higher than the ones in the edge in all types of pilothole. 


\section{SWS curves}

Figure 3 shows a typical curve for SWS for in each type of pilot holes. The graph shows that the SWS values reach at the maximum about $8 \mathrm{sec}$. All SWS curves tended to have similar trend.

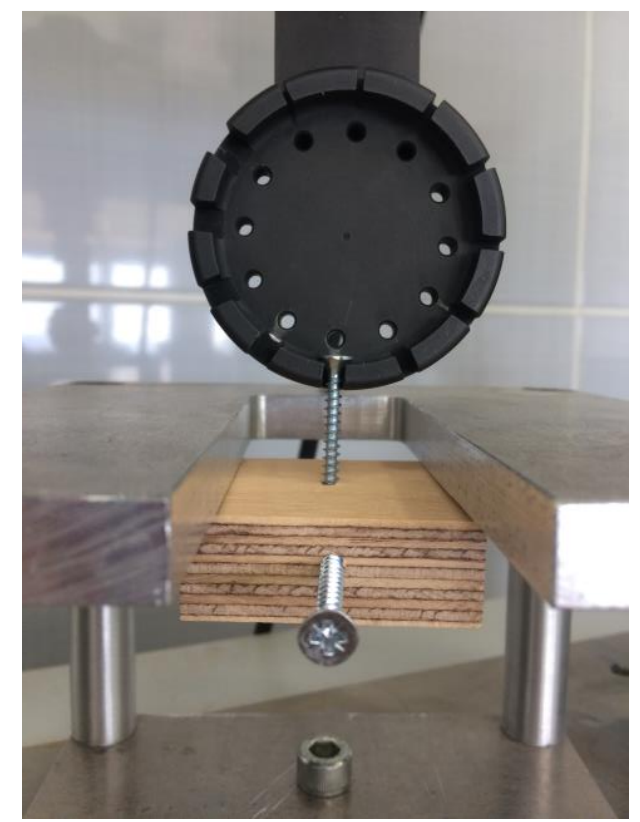

Figure 2. SWS test setup

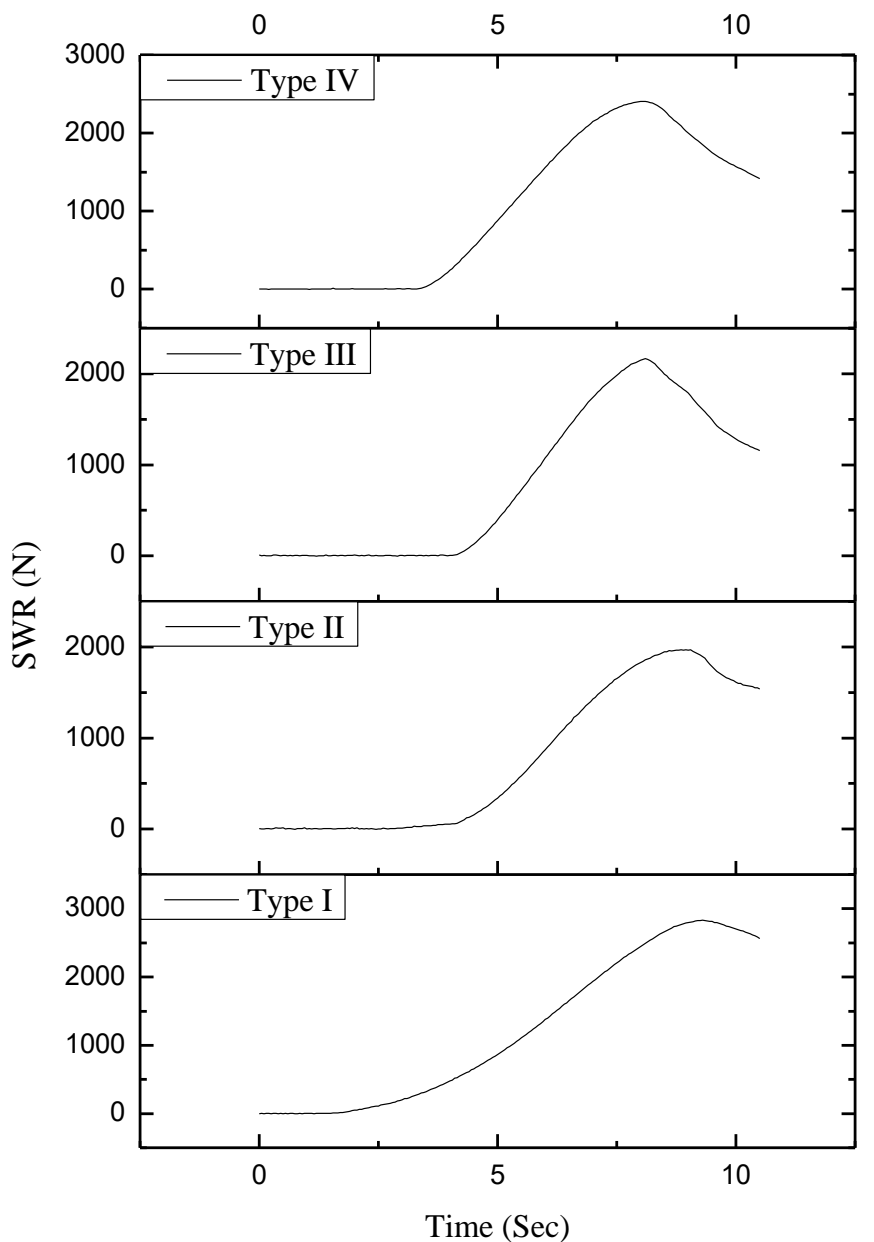

Figure 3. Load-time curve of direct screw withdrawal test for the type of pilot-holes 
Table 1. Mean withdrawal strength and their standard deviation in each combination

\begin{tabular}{|c|c|c|c|c|c|}
\hline $\begin{array}{l}\text { Major diameter } \\
\text { of screw } \\
\text { (mm) }\end{array}$ & Water soak & $\begin{array}{l}\text { Embedded } \\
\text { screw } \\
\text { orientation }\end{array}$ & $\begin{array}{c}\text { Type of } \\
\text { pilot-hole }\end{array}$ & $\begin{array}{l}\text { Mean } \\
(\mathrm{N})\end{array}$ & $\begin{array}{l}\text { Standard } \\
\text { deviation } \\
(\mathrm{N})\end{array}$ \\
\hline \multirow{16}{*}{3.5} & \multirow{8}{*}{ 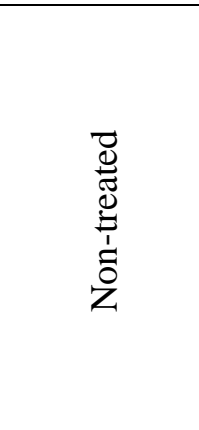 } & \multirow{4}{*}{ Face } & I & $3217(4)^{\mathrm{a}}$ & 126 \\
\hline & & & II & $2265(6)$ & 126 \\
\hline & & & III & $2349(8)$ & 185 \\
\hline & & & IV & $3042(3)$ & 86 \\
\hline & & \multirow{4}{*}{ Edge } & I & 2381 (17) & 411 \\
\hline & & & II & 1573 (10) & 165 \\
\hline & & & III & $1852(9)$ & 166 \\
\hline & & & IV & 2575 (13) & 340 \\
\hline & \multirow{8}{*}{ 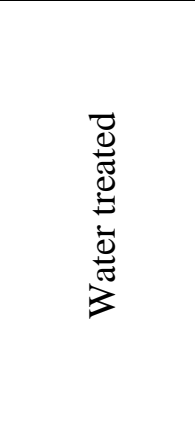 } & \multirow{4}{*}{ Face } & I & $3114(6)$ & 179 \\
\hline & & & II & $1562(6)$ & 96 \\
\hline & & & III & 2597 (7) & 184 \\
\hline & & & IV & $3142(9)$ & 298 \\
\hline & & \multirow{4}{*}{ Edge } & I & $1601(17)$ & 266 \\
\hline & & & II & $713(6)$ & 40 \\
\hline & & & III & 1563 (18) & 278 \\
\hline & & & IV & $2125(15)$ & 329 \\
\hline \multirow{16}{*}{4.0} & \multirow{8}{*}{ 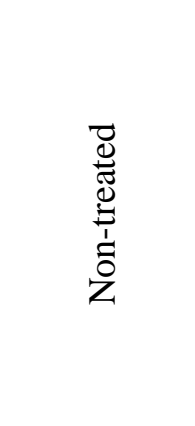 } & \multirow{4}{*}{ Face } & I & $3371(8)$ & 261 \\
\hline & & & II & 2993 (8) & 247 \\
\hline & & & III & 2570 (10) & 267 \\
\hline & & & IV & $3402(7)$ & 223 \\
\hline & & \multirow{4}{*}{ Edge } & I & $2569(5)$ & 118 \\
\hline & & & II & 2096 (11) & 238 \\
\hline & & & III & 2254 (19) & 419 \\
\hline & & & IV & $3138(6)$ & 179 \\
\hline & \multirow{8}{*}{ 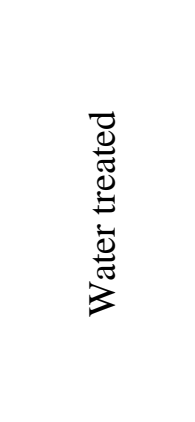 } & \multirow{4}{*}{ Face } & I & 3037 (6) & 191 \\
\hline & & & II & $2231(7)$ & 166 \\
\hline & & & III & 2713 (9) & 239 \\
\hline & & & IV & $3643(5)$ & 193 \\
\hline & & \multirow{4}{*}{ Edge } & I & $1421(4)$ & 55 \\
\hline & & & II & 1313 (14) & 183 \\
\hline & & & III & 1902 (13) & 238 \\
\hline & & & IV & $2965(9)$ & 254 \\
\hline
\end{tabular}

${ }^{\mathrm{a}}$ Values in parentheses are coefficient of variance (\%).

\section{Mean SWS comparisons}

A general linear model of analysis of variance (ANOVA) was performed to analyze significances of four main effects and their interactions on the SWS data sets at the $5 \%$ significance level using SAS 9.4 software (SAS Institute INC 1999). ANOVA results indicated that the four-factor and all threefactor interactions of data set was not significant except the three-factor interaction among screw major diameter, embedded screw orientation and type of pilot-holes. Therefore, a one-way classification of 16 treatment combinations was created for SWS 
data set to evaluate mean differences among these combinations using the protected least significant difference (LSD) multiple comparisons procedure. Table 2, 3 and 4 summarize mean comparison of SWS values for type of pilot-hole effect, embedded screw orientation effect and water soak based on the LSD value of $288.58 \mathrm{~N}$, respectively.

\section{Pilot-hole effects.}

The withdrawal load using the PU as mounting adhesive in pilot-holes was higher than type I, II and III in all combination of embedded screw orientation and water soak (Table 2). This situation can be explained; PU adhesive effectively wet the surface of most materials (metal, wood, plastic, ceramic) and develop excellent bonding (Kong et al. 2011).
Pizzi and Mittal (2003) stated that polyurethane adhesives have a higher bonding strength and a higher tolerance against humidity. According to another study, PU is the least affected one compared to PVAc in the steam test (Yorur et al. 2014).

In the case of comparing type I and II, the screw withdrawal load was significantly higher when no pilot-hole was driven in face and edge of testing blocks. This could be explained by when driving screw into the material, the screw seated better in the material without pilot-hole, having any failure. In a study by Que et all (2014), it was noted that as the pilot hole diameter increases, the screw withdrawal strength decreases due to less contact area between the screw and testing block of wood lumber.

Table 2. Mean comparison of SWS in type of pilot-hole

\begin{tabular}{cccccc}
\hline \multirow{2}{*}{ Water soak } & \multirow{2}{*}{ Embedded screw orientation } & \multicolumn{4}{c}{ Type of pilot-hole } \\
\cline { 3 - 6 } & & $\mathrm{I}$ & $\mathrm{II}$ & $\mathrm{III}$ & $\mathrm{IV}$ \\
\hline \multirow{2}{*}{ Non-treated } & Face & $3294 \mathrm{~A}$ & $2629 \mathrm{~B}$ & $2460 \mathrm{~B}$ & $3222 \mathrm{~A}$ \\
\multirow{3}{*}{ Water treated } & Edge & $2475 \mathrm{~B}$ & $1834 \mathrm{C}$ & $2053 \mathrm{C}$ & $2857 \mathrm{~A}$ \\
\cline { 2 - 5 } & Face & $3075 \mathrm{~B}$ & $1896 \mathrm{D}$ & $2655 \mathrm{C}$ & $3392 \mathrm{~A}$ \\
& Edge & $1511 \mathrm{~B}$ & $1013 \mathrm{C}$ & $1732 \mathrm{~B}$ & $2545 \mathrm{~A}$ \\
\hline
\end{tabular}

${ }^{a}$ Means followed by a common letter are not significantly different at the 5\% level.

Embedded screw orientation effects.

Table 3 summarizes the mean comparison of SWS values for embedded screw orientation in each type of pilot-hole driven into material within water soak. ANOVA results indicated that the SWS was higher where screw was driven into the face of the specimen than edge of the specimen in all combination of type of pilothole and water soak.

Table 3. Mean comparison of SWS in embedded screw orientation

\begin{tabular}{cccc}
\hline \multirow{2}{*}{ Water soak } & \multirow{2}{*}{ Type of pilot-holes } & \multicolumn{2}{c}{ Embedded screw orientation } \\
\cline { 3 - 4 } & & Face & Edge \\
\hline \multirow{3}{*}{ Non-treated } & I & $3294 \mathrm{~A}^{\mathrm{a}}$ & $2475 \mathrm{~B}$ \\
& II & $2629 \mathrm{~A}$ & $1834 \mathrm{~B}$ \\
& III & $2460 \mathrm{~A}$ & $2053 \mathrm{~B}$ \\
& IV & $3222 \mathrm{~A}$ & $2857 \mathrm{~B}$ \\
\hline \multirow{3}{*}{ Water treated } & I & $3075 \mathrm{~A}$ & $1511 \mathrm{~B}$ \\
& II & $1896 \mathrm{~A}$ & $1013 \mathrm{~B}$ \\
& III & $2655 \mathrm{~A}$ & $1732 \mathrm{~B}$ \\
& IV & $3392 \mathrm{~A}$ & $2545 \mathrm{~B}$ \\
\hline
\end{tabular}

${ }^{a}$ Means followed by a common letter are not significantly different at the 5\% level. 
Water soak effects.

Table 4 summarizes the mean comparison of SWS values for water soak in each type of pilot-hole driven into face and edge of plywood material. The testing blocks immersed in water had statistically lower SWS than the ones had no water immersion in the edge of testing blocks within all types of pilot-holes. Similarly, the SWS was affected negatively in the face of testing block which had no predrilling as having lower SWS in the testing blocks immersed in water. A similar study showed that SWS decreased with water soak (Yorur 2016). However, there was no statistically significant difference in SWS among the pilot-hole types I, III, IV.

Table 4. Mean comparison of SWS for water soak

\begin{tabular}{cccc}
\hline \multirow{2}{*}{$\begin{array}{c}\text { Embedded screw } \\
\text { orientation }\end{array}$} & Type of pilot-hole & \multicolumn{2}{c}{ Water soak } \\
\cline { 3 - 4 } & I & Non-treated & Water treated \\
\hline \multirow{2}{*}{ Face } & II & $2629 \mathrm{~A}^{\mathrm{a}}$ & $3075 \mathrm{~A}$ \\
& III & $2460 \mathrm{~A}$ & $1896 \mathrm{~B}$ \\
& IV & $3222 \mathrm{~A}$ & $3392 \mathrm{~A}$ \\
\hline \multirow{3}{*}{ Edge } & I & $2475 \mathrm{~A}$ & $1511 \mathrm{~B}$ \\
& II & $1834 \mathrm{~A}$ & $1013 \mathrm{~B}$ \\
& III & $2053 \mathrm{~A}$ & $1732 \mathrm{~B}$ \\
& IV & $2857 \mathrm{~A}$ & $2545 \mathrm{~B}$ \\
\hline
\end{tabular}

${ }^{\mathrm{a}}$ Means followed by a common letter are not significantly different at the 5\% level.

\section{Screw major diameter effects.}

Based on the ANOVA results, the main effect of screw major diameter was also created since only three-factor interaction among embedded screw orientation, type of pilot-hole and water soak was significant. Therefore, a one-way classification of 2 treatment combinations was created for SWS data set to evaluate mean differences between screw major diameter using the protected least significant difference (LSD) multiple comparisons procedure. Table 5 summarizes mean comparison of SWS values for screw major diameter on the LSD value of $223.64 \mathrm{~N}$.
LSD results indicated that the screw major diameter of $4 \mathrm{~mm}$ had higher SWS than the $3.5 \mathrm{~mm}$. Similarly, the higher SWS values was obtained when the screw major diameter increased from 4 to $6 \mathrm{~mm}$ which resulted in increasing the shear strength with enlarge the contact area between screw and testing block of bamboo lumber. (Chen et al, 2016). The screw withdrawal load was higher when the screw major diameter increased from 3.6 to 7 $\mathrm{mm}$ and the depth of penetration increased from $9.5 \mathrm{~mm}$ to $57 \mathrm{~mm}$ (The Engineered Wood Association, 1997).

Table 5. Mean comparison of screw withdrawal load for screw major diameter

\begin{tabular}{ccc}
\hline & \multicolumn{3}{c}{ Major diameter of screw $(\mathrm{mm})$} \\
\cline { 2 - 3 } & 3.5 & 4 \\
\hline Screw withdrawal load $(\mathrm{N})$ & $2229 \mathrm{~B}^{\mathrm{a}}$ & $2601 \mathrm{~A}$ \\
\hline${ }^{\mathrm{a}}$ Means followed by a common letter are not significantly different at the 5\% level.
\end{tabular}




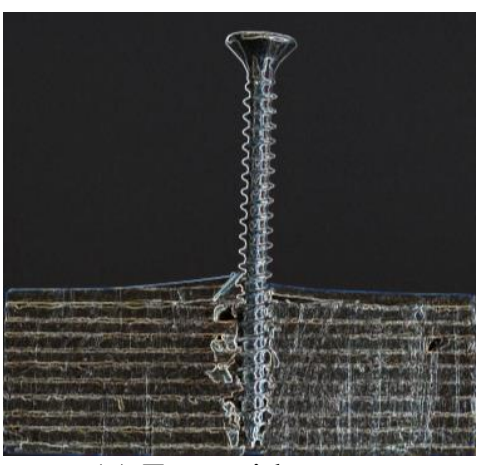

(a) Face with screw

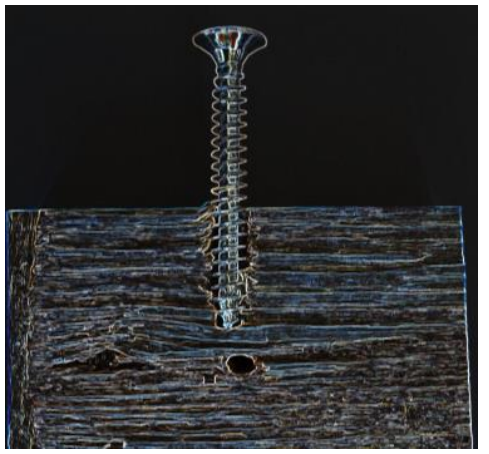

(c) Edge with screw

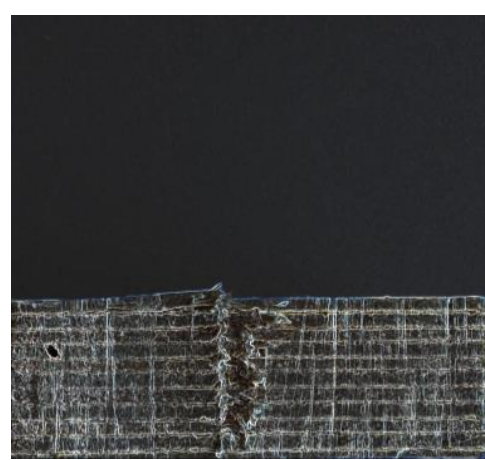

(b) Face with no screw

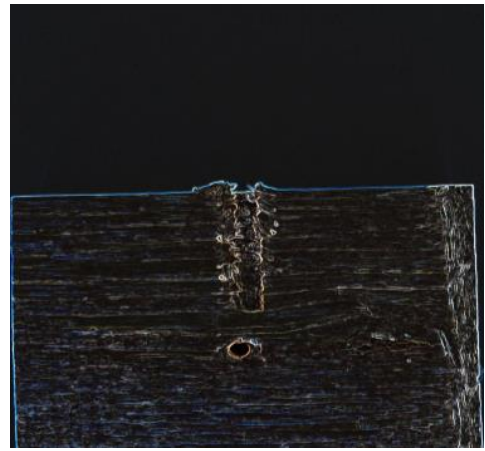

(d) Edge with no screw

Figure 4. Interior view of face $(\mathrm{a}, \mathrm{b})$ and edge $(\mathrm{c}, \mathrm{d})$ specimen after screw withdrawal test

\section{Conclusions}

The use of screws in the construction made of plywood has become increasingly popular. In order to have better screw withdrawal strength, there are some factors such as pilothole diameter, embedded screw orientation, adding adhesive into the pilot-holes and predrilling before driving screw into plywood to be considered carefully. This study reported that applying PU as mounting adhesive into pilot-holes in edge and face of plywood had better screw holding capacity than the one had no glue and no pilot-hole (type I) and only pilot-hole (type II) and applied with PVAc. Another important result showed that no matter what type of pilot-hole were used and whether the testing blocks were immersed in water or not, the SWS was higher in the face of plywood than the one in edge.

\section{References}

Akyıldız, M. and Malkocoglu, S. (2001).

Wood screw withdrawal resistance of some important tree species growing in Eastern Blacksea region. J Artvin Forest Faculty Kafkas University, 2(1), 54-60.
APA. (1997). Panel Handbook \& Grade Glossary, The Engineered Wood Association,

BS EN 320 (1993). Fibreboards Determination of resistance to axial withdrawal of screws. British Standards Institution, 1-6.

Carroll, M.N. (1970). Relationship between driving torque and screw-holding strength in particleboard and plywood. Forest Prod $J, 20(3), 24-29$.

Celebi, G. and Kilic, M. (2007). Nail and screw withdrawal strength of laminated veneer lumber made up hardwood and softwood layers. Construction and Building Materials, 21(4), 894-900.

Chen, Y., Zhu, S., Guo, Y., Liu, S., Tu, L. and Fan, H. (2016). Investigation on withdrawal resistance of screws in reconstituted bamboo lumber. Wood Research, 61(5), 799-810.

Eckelman, C.A. (1973). Holding strength of screws in wood and wood-based materials. Res. Rept. No. 895. Purdue University Agric. Expt. Sta., 15. 
Eckelman, C.A. (1975). Screw-holding performance in hardwoods and particleboard. Forest Products Jornal, 25(6), 30-35.

Eckelman, C.A. (1978). Predicting withdrawal strength of sheet-metal-type screws in selected hardwoods. Forest Prod $J, 28(8), 25-8$.

Eckelman, C.A. (1988). The withdrawal strength of screws from a commercially available medium density fiberboard, Forest Products Journal, 35(5), 21-24.

Eckelman, C. A. (1990). A Review and Summary of Relevant Published Literature on Fasteners and Their Use with Particleboard and MDF. National Particleboard Association, 11, 14-90.

Eckelman, C.A. and Rajak, Z.A. (1993). Edge and face withdrawal strength of large screws in particleboard and medium density fiberboard. Forest Product Journal, 43(4), 25-30.

Erdil, Y.Z., Zang, J. and Eckelman, C.A. (2002). "Withdrawal and bending strength of dowel-nuts in plywood and oriented strand board" Forest Product Journal 53(6), 54-57.

Ferah, O. (1991). Determination of withdrawal strength screw and nail in some important trees. Inst Forest Res Tech Bull, 252, 51-72.

Fujimoto, Y. and Mori, M. (1983). Performance of wood screw joints for particleboard. Bull Fac Agr Kyushu Univ Jpn, 38(1), 45-7.

Kong, X., Liu, G., \& Curtis, J. M. (2011). Characterization of canola oil based polyurethane wood adhesives. International Journal of Adhesion and Adhesives, 31(6), 559-564.

Ors, Y, Ozen, R. and Doganay, S. (1998). Screw holding ability of wood materials used in furniture manufacture. Turk $J \mathrm{Agr}$ Forest, 22(4), 29-34.

Ozen, R. (1988). Genel Hatlarıyla Türkiye Mobilya Sanayi, Gazi University Journal of Tec. Edu. Fac., 1(3), 3-9.

Ozcifci, A. (2009). The effects of pilot hole, screw types and layer thickness on the withdrawal strength of screws in laminated veneer lumber, Journal of Materials \& Design, 30, 2355-2358. Doi: 10.1016/j.matdes.2008.11.001.
Pizzi A, Mittal KL. (2003). Handbook of adhesive technology. 2nd ed. Monticello, NY: Marcel Dekker Inc.

Rajak. Z. and Eckelman, C.A. (1993). Edge and face withdrawal strength of large screws in particleboard and medium density fiberboard. Forest Prod J, 43(4), 25-30.

Rammer, D.R. (1999). Wood handbook: wood as an engineering material, chapter 8. US Department of Agriculture Forest Service, Forest Products Laboratory, 8.128.

SAS Institute INC. (1999). SAS/STAT User's Guide, Version 8. Cary, NC.

Senay, A. (1996). Technological properties of laminated wood material (Ph.D thesis). Istanbul University, Istanbul.

Tor, O., Yu, X.H., Zhang, J. (2015). Characteristics of torques for driving screws into wood-based composites. Wood Fiber Sci 47(1), 4-5

Tor, O., Demiel, S., Hu, L. and Zhang, J. (2016). Effcts of Driving Torques on Direct Screw Withdrawal Resistance in OSB. Kastamonu Univ. Journal of Forestry Faculty, 16(2), 438-446.

TS EN 13446 (2005). Wood - based panels Determination of withdrawal capacity of fasteners. Institute of Turkish Standards. 17.

Que, Z.L., Yang, L., Wang, F.B., Zhu, X.N. and Pan, B. (2014). Effects of vessel diameter on screw withdrawal strength in dimension lumber of wood structure. Journal of Northwest Forestry University 29(5), 195-198.

Yorur, H. (2016). Utilization of Waste Polyethylene and its Effects on Physical and Mechanical Properties of Oriented Strand Board. BioResources, 11(1), 24832491.

Yorur, H., Kurt, Ş., Uysal, B. (2014). Bonding strength of oak with different adhesives after humid-water-heat tests. Journal of Adhesion Science and Technology, 28(7), 690-701. 